\title{
A Multivariate Analysis of Artificially Deformed Patagonian Skulls
}

\author{
Marta Graciela Méndez, Susana Alicia Salceda, \\ and María Fernanda López ARMEngol \\ Universidad Nacional de la Plata \\ and Consejo Nacional de Investigaciones Científicas y Técnicas, \\ La Plata, Provincia de Buenos Aires, República Argentina
}

Received July 23, 1996

\begin{abstract}
The quantitative variables related to aspects of prehistoric populations of Patagonia and Fueguía were analyzed. Skulls from adult individuals of both sexes, 100 deformed and 100 undeformed ones, were studied. Thirty-four linear and angular variables described by Herrera Fritot (1964) based on the sagittal profile were recorded. Data matrices, one for each sample (deformed and undeformed), were computed. Both samples were analyzed by principal components analysis and cluster techniques. Variables with major discriminatory power for each sample were obtained. Results were compared and four sets of variables were delimited. The first one consisted of variables which shared discriminatory power between both the deformed and undeformed skulls; the second set includes those which deal with the variation for undeformed skulls; the third set with the variation for deformed skulls, and the fourth set did not provide any important contributions dealing with the intrasample variation. Differences among variables by region were also analyzed.
\end{abstract}

Key Words: craniogeometry, principal components, artificial deformation, Patagonia, Fueguía

\section{INTRODUCTION}

The human skull is a complex of interrelated functional units. The nature and extent of the interdependence of these units have been analyzed and discussed (Stamrud, 1959; Moss and Young, 1960; Anton, 1989). Classically, craniometry has been the procedure for undertaking the descriptive and comparative study of skull morphology.

When a dynamic vision was necessary, the analysis was centred on the geometric or trigonometric relationship rather than on the purely descriptive ones. Together with the theoretical views on man's origin and evolution, studies intended to provide a dynamic vision of the equilibrium between different skull regions were developed. Lissauer (1885) was the first one to use a diagram of sagittal plane called the "sagittal norm." Sollas (1933) made comparative studies on hominid skulls. Klaatsch (1909), Falkenburger $(1912,1913,1938,1941)$ and Tedeschi (1916) developed a series of geometric variables on the same norm that allowed for the determination of the relationships of different skull regions to each other. 
It was realized that an analysis of the relationships between the cranial and facial skeletons was of importance in the study of deformed skulls. Imbelloni (1921) and Herrera Fritot (1964) organized an integrated system, i.e., the sagittal diagram for the variables on these skeletons. The application of this methodology to the analysis of deformed and undeformed skulls permitted the interpretation not only of the organic response to external stress but also of the mechanisms of coordination among skull regions during the ontogenetic development.

The purpose of this paper is to examine: 1- which variables express the structural modifications of the skull caused by artificial deformation; 2- which variables do not suffer modifications by artificial deformation and express the natural variation of the population; 3- which variables remain related for undeformed and deformed skulls.

The selection of Patagonian skulls was based on the results of previous studies which describe the presence of all the well-known deformation types in the region, all of them having a long chronological and biodynamic history (Marelli, 1914, 1919; Bórmida, 1953/54; Colantonio and Marcellino, 1983; Colantonio et al., 1984; Méndez and Salceda, 1995; among others). This circumstance, with the facts that the region is located in the southernmost area of America and that a great number of skulls have been taken from it, makes the region interesting to study.

\section{MATERIAL AND METHODS}

The study was carried out on 200 skulls from adults of both sexes. The skulls are housed in Museo de la Plata, Argentina. Most of them were collected by researchers and naturalists at the end of the nineteenth century and the beginning of the twentieth century (Table 1, Fig. 1). Only skulls in a good state of preservation were studied. The sample was divided into two categories, "undeformed" and "deformed." One-hundred "undeformed" and 100 "deformed" skulls were examined. Of the deformed skulls, 79 bear tabular and 21 circular deformation. Sex and age were determined according to the recommendations of the European Anthropologist Group (Ferembach et al., 1977/ 78). No differences between sexes were found for the geometric variables used herein. Deformation types were determined after Dembo and Imbelloni (1938). Only skulls with typical deformation were included.

Table 1. Number of the skulls used from the different provinces

\begin{tabular}{lcc}
\hline PROVINCE & $\begin{array}{c}\text { UNDEFORMED } \\
\mathrm{n}=100\end{array}$ & $\begin{array}{c}\text { DEFORMED } \\
\mathrm{n}=100\end{array}$ \\
\hline Tierra del Fuego & 7 & 7 \\
Santa Cruz & 7 & 4 \\
Chubut & 57 & 46 \\
Río Negro & 29 & 43 \\
\hline
\end{tabular}




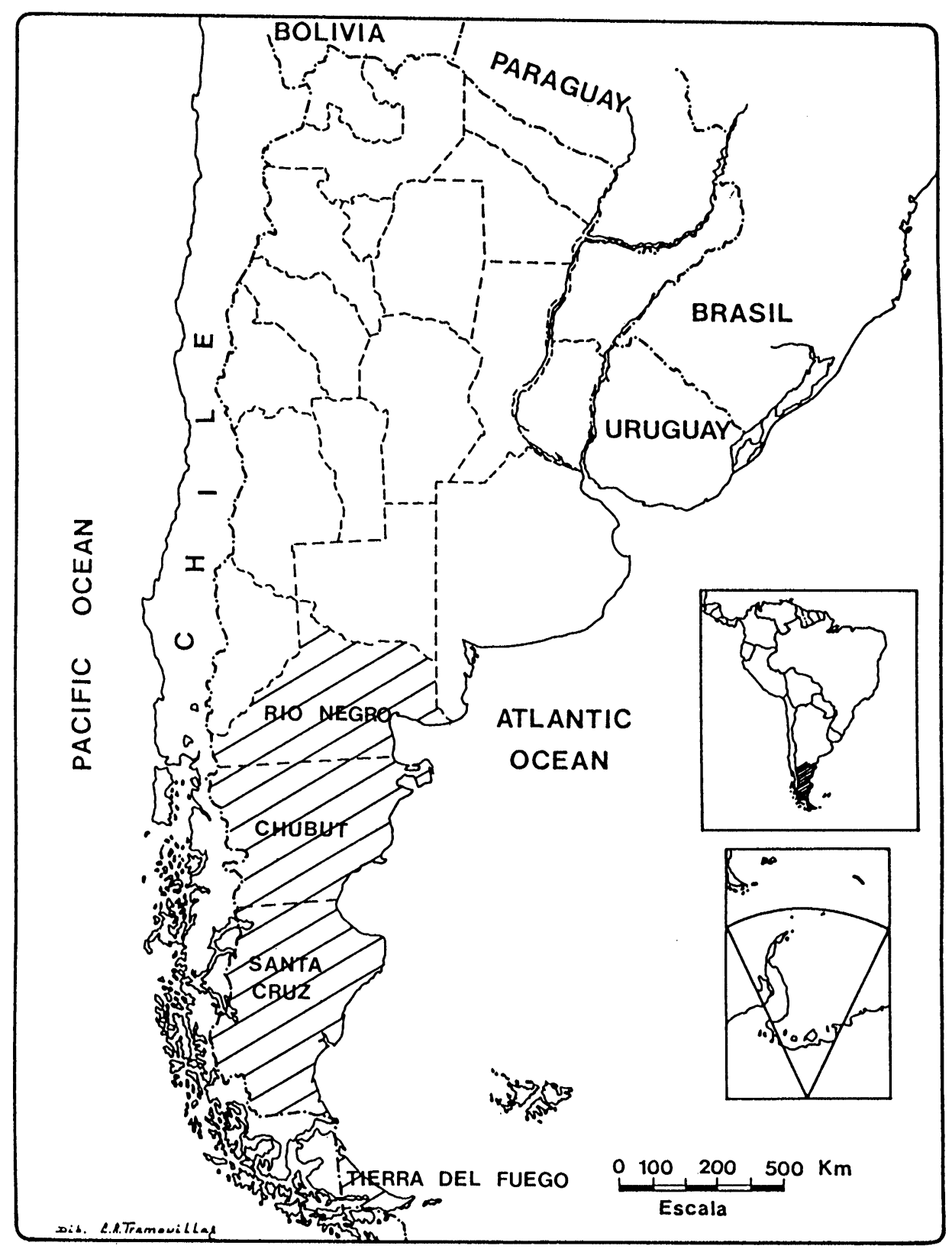

Fig. 1. Map of Argentina showing the regions where the skulls come from.

For each skull the sagittal profile and 34 linear and angular variables were recorded (Table 2 and Figs. 2, 3). The technique was described by Imbelloni (1921) and Herrera Fritot (1964). Two data matrices were made, one for undeformed and the other for deformed skulls. Each matrix is of 100 skulls with 34 variables.

Data processing. NTSYS-pc programs (Numerical Taxonomy and Multivariate 


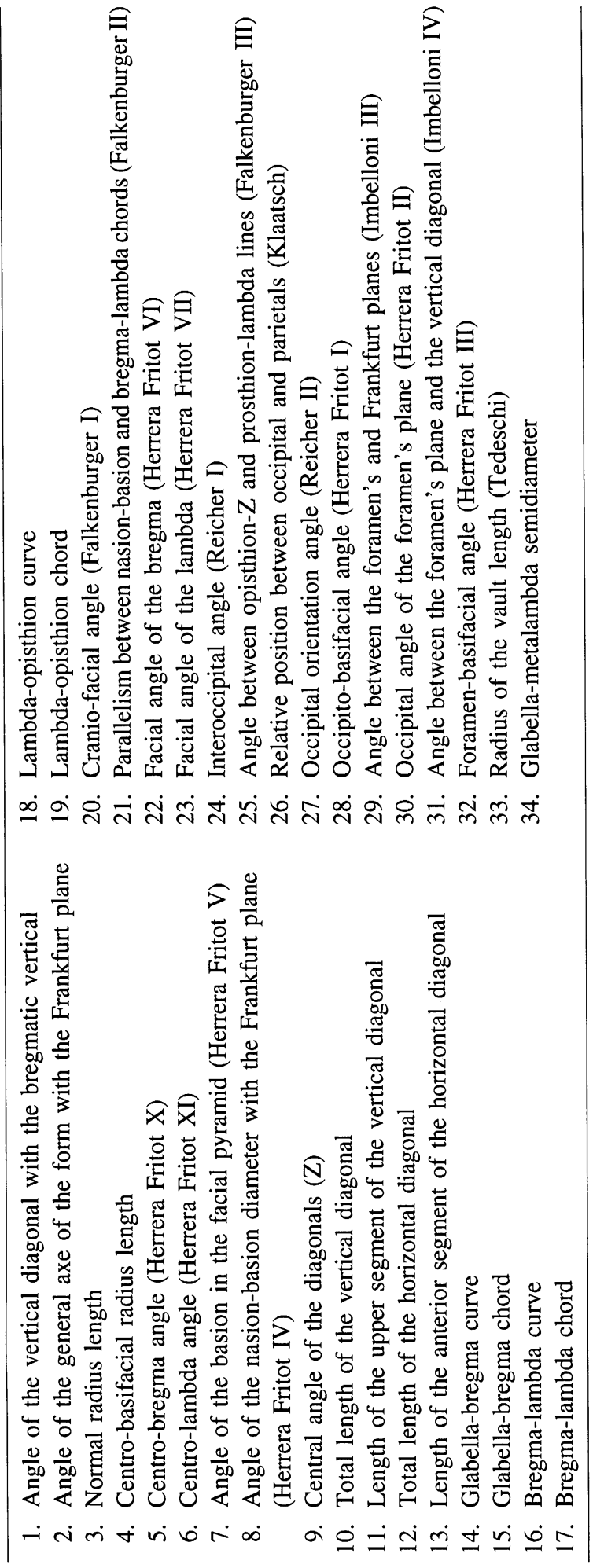




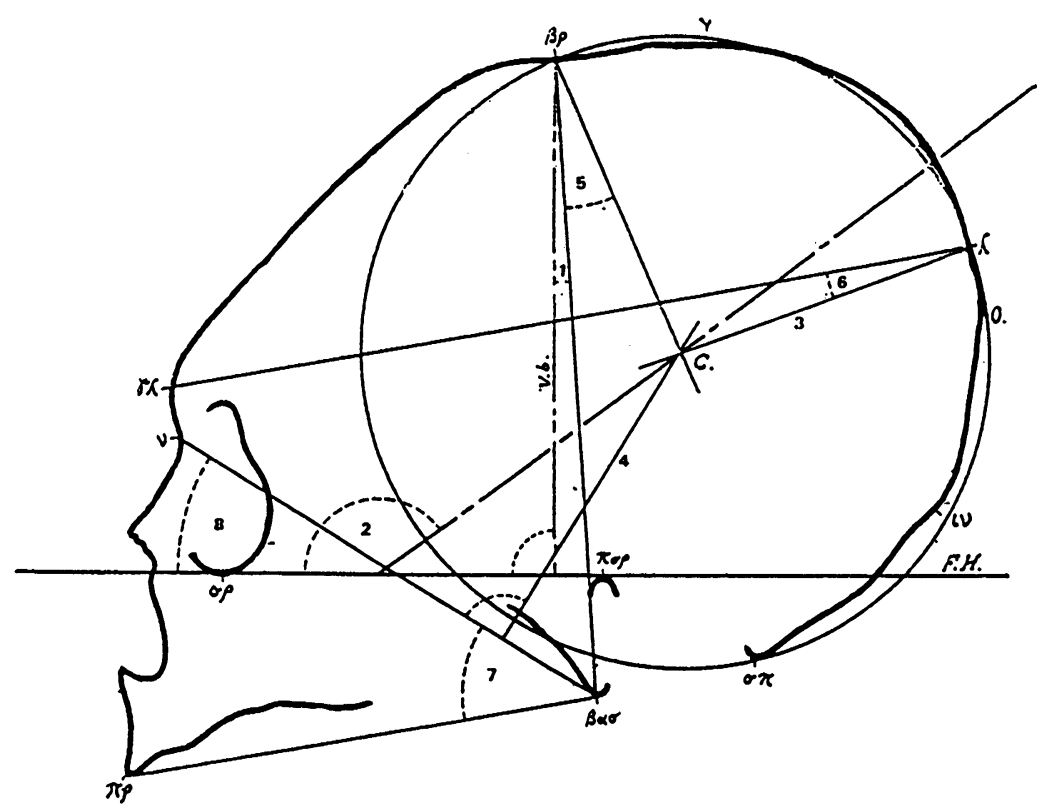

a

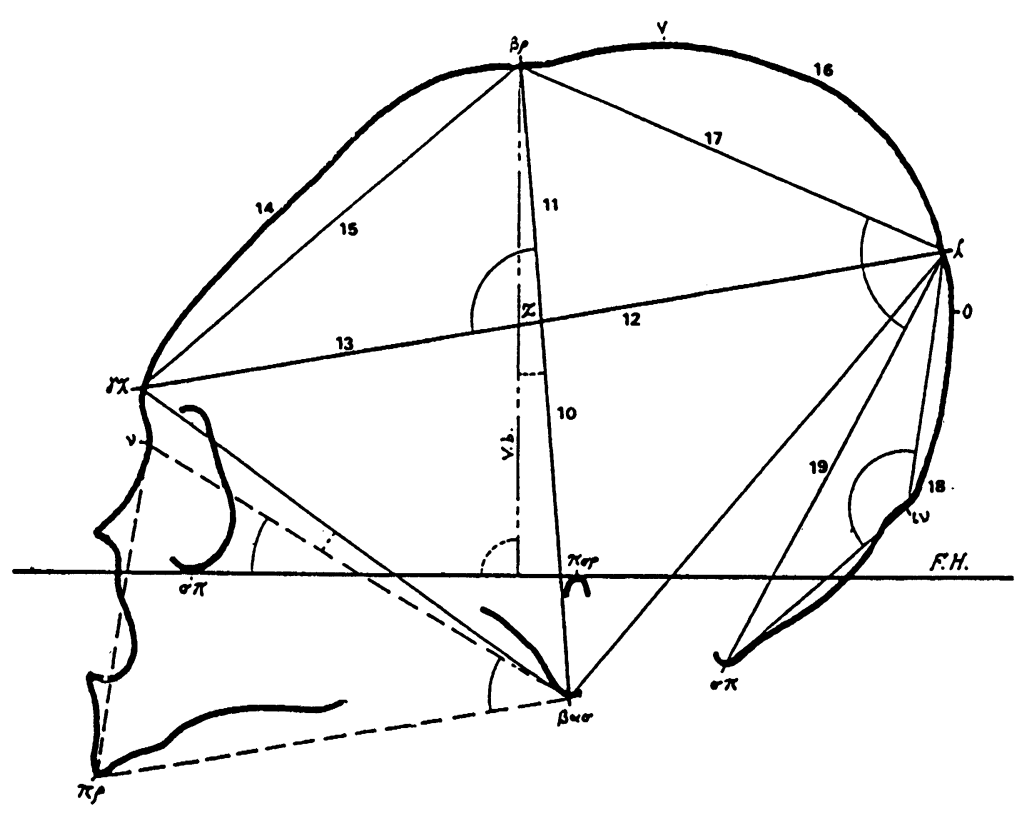

Fig. 2. Sagittal norm with the linear and angular variables recorded: a) variables 1 to 8 ; b) variables 9 to $19 . \pi \rho=$ prosthion; $\nu=$ nasion; $\gamma \lambda=$ glabella; $\sigma \rho=$ orbitale; $\beta \rho=$ bregma; $\tau=$ vertex; $\lambda=$ lambda; $\mathrm{o}=$ opisthokranion; $\beta \alpha \sigma=$ basion; $\sigma \pi=$ opisthion; $\iota \nu=$ inion; $\pi \mathrm{o} \rho=$ porion; F.H.=Frankfurt horizontal. 

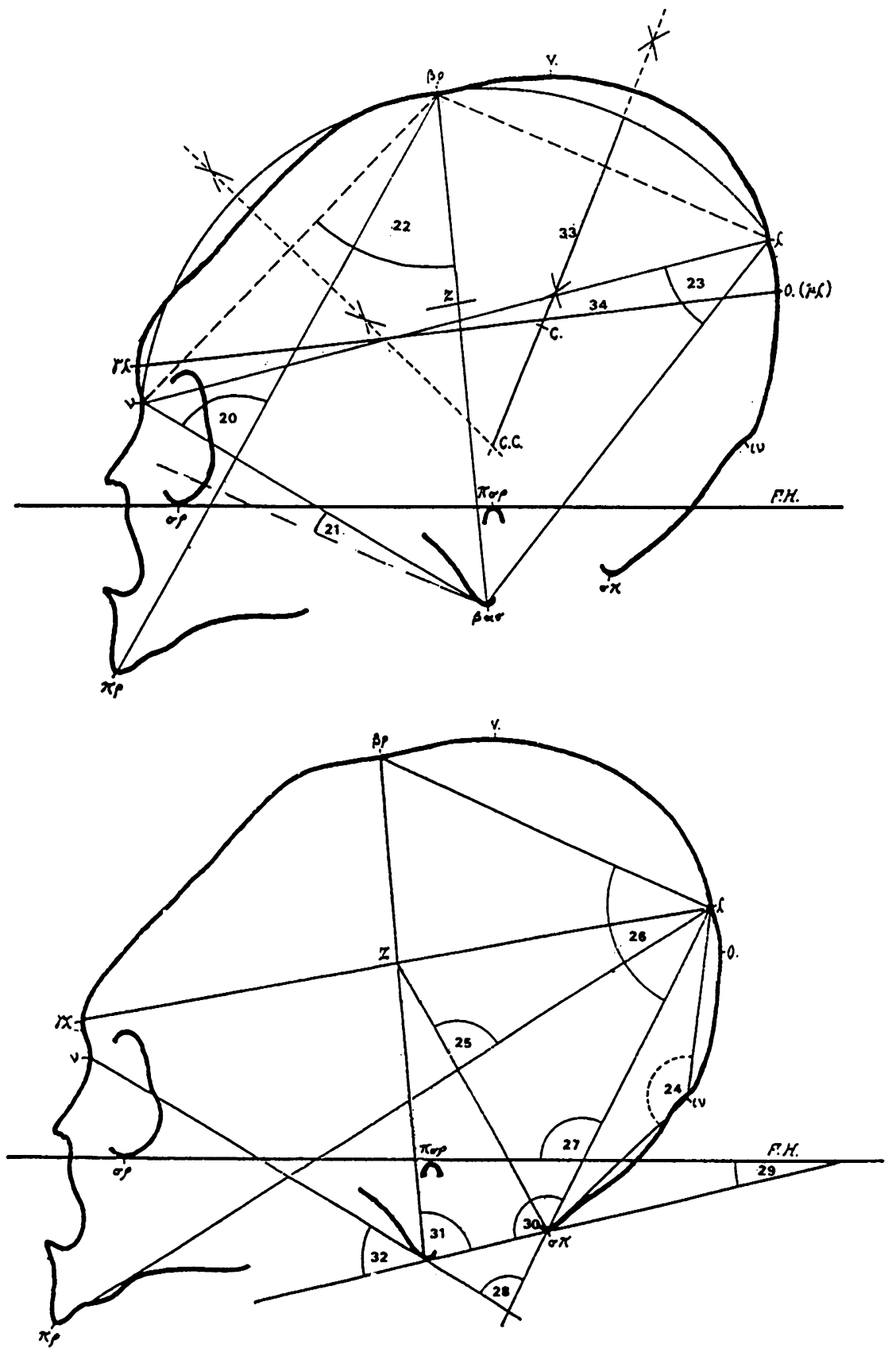

Fig. 3. Sagittal norm with the linear and angular variables recorded: a) variables 20 to 23 and $33-$ 34 ; b) variables 24 to $32 . \pi \rho=$ prosthion; $\nu=$ nasion; $\gamma \lambda=$ glabella; $\sigma \rho=$ orbitale; $\beta \rho=$ bregma; $\tau=$ vertex; $\lambda=$ lambda; $0 . \quad(\gamma \mu \lambda)=$ opisthokranion; $\beta \alpha \sigma=$ basion; $\sigma \pi=$ opisthion; $\iota \nu=$ inion; $\pi \sigma \rho=$ porion; F.H. $=$ Frankfurt horizontal. 
Analysis System; Rohlf, 1992) were used. The data of both matrices were analyzed by two methods of R technique, principal component analysis (PCA) and cluster analysis. For each pair of variables a coefficient correlation was calculated. Then, PCA was applied to the matrices and the axes or components were obtained. This methodology allowed to know the discriminatory value of the variables as well as the contribution of each of them to the total variation.

The UPGMA (Unweighted pair group method using arithmetic averages) technique was applied to the matrices in order to know which sets of variables are related. Two phenograms of the 34 variables were obtained. Phenogram I and phenogram II exhibit the relationships among the variables in undeformed and deformed skulls, respectively. The distortion produced by making the phenogram was evaluated by means of the cophenetic correlation coefficient (C.C.C., Sokal and Rohlf, 1962). Both phenograms were analyzed with the strict consensus method to identify common groups (Sokal and Rohlf, 1981). Two different consensus indexes were computed. One, called CI, is based on the number of distinct subsets (excluding the set of all the variables) on a strict consensus tree (Schuh and Polhemus, 1980). Another, called CIc, expresses the proportion of the possible subsets to the number of variables that are present in the consensus tree from two classifications. The latter varies between 0 and 1 , where 1 is the maximum congruence (Rohlf, 1982).

\section{RESULTS}

The results of the PCA are shown in Tables 3 and 4. The differences between them are attributed to the changes by deformation in the discriminatory expression of the variables. Different sets of variables can be distinguished: variables with discriminatory value only for the undeformed skulls (34-19-21-27-23-31), variables with discriminatory value only for the deformed skulls (33-11-17-16-14-32-29), variables with discriminatory value for both samples (4-12-5-26-6-10-28-3), and variables not included in the previous cases (1-2-7-8-9-13-15-18-20-22-24-25-30).

The analysis of the variables in the correlation phenogram for undeformed skulls (Fig. 4) shows the following clusters: 23-26; 31-32, 22-25; 3-10; 16-17; 12-34; 13-15$14 ; 4-5 ; 29-30 ; 27-28$ and $6-18-19-21$. The phenogram of variables for deformed ones (Fig. 5) depicts the following clusters: $1-26 ; 3-10 ; 16-17 ; 31-32 ; 27-28 ; 4-33-5 ; 12-34$; 13-15-14; 6-21-18-19; 9-24 and 7-8.

Two kinds of variables were observed in the strict consensus tree (Fig. 6), those that remain clustered in both phenograms $(3-10 ; 6-18-19-21 ; 12-34 ; 13-15-14 ; 16-17 ; 27-$ 28 and 31-32) and others that change their relationships (1, 2, 4, 5, 7, 8, 9, 11, 20, 22 to $26,29,30,33)$. The values of the consensus indexes were: $\mathrm{CI}=8$, because there are 8 subsets of variables in both trees, and CIc $=0.25$ showing a low congruence.

The analysis of the seventeen variables that change their relationships shows: 1- two pairs of variables that remain correlated only in undeformed (22-25 and 29-30); 2- two 


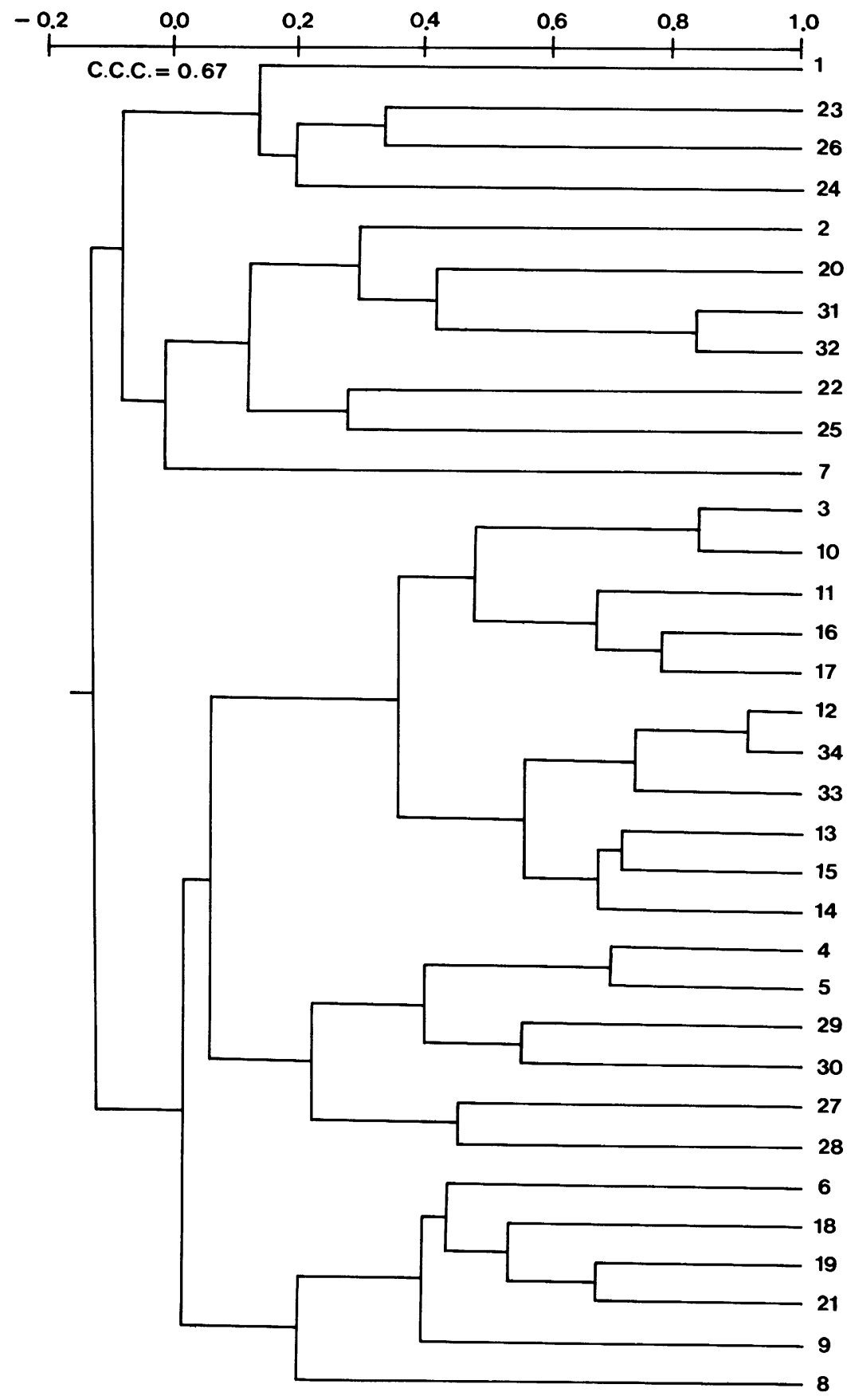

Fig. 4. Undeformed skulls. Correlation phenogram (U.P.G.M.A.) of the 34 craniogeometric variables. CCC: Cophenetic correlation coefficient. 


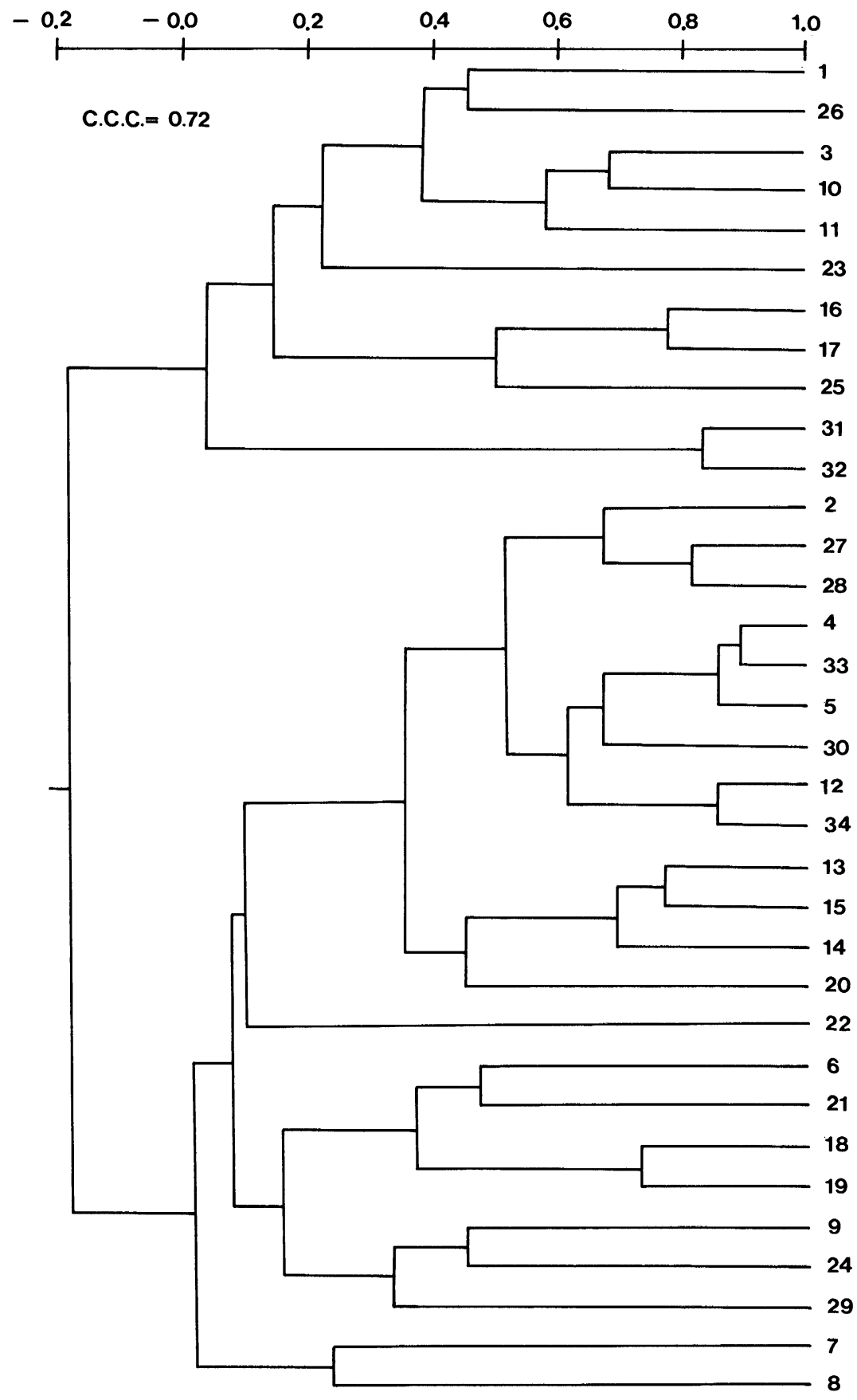

Fig. 5. Deformed skulls. Correlation phenogram (U.P.G.M.A.) of the 34 craniogeometric variables. CCC: Cophenetic correlation coefficient. 


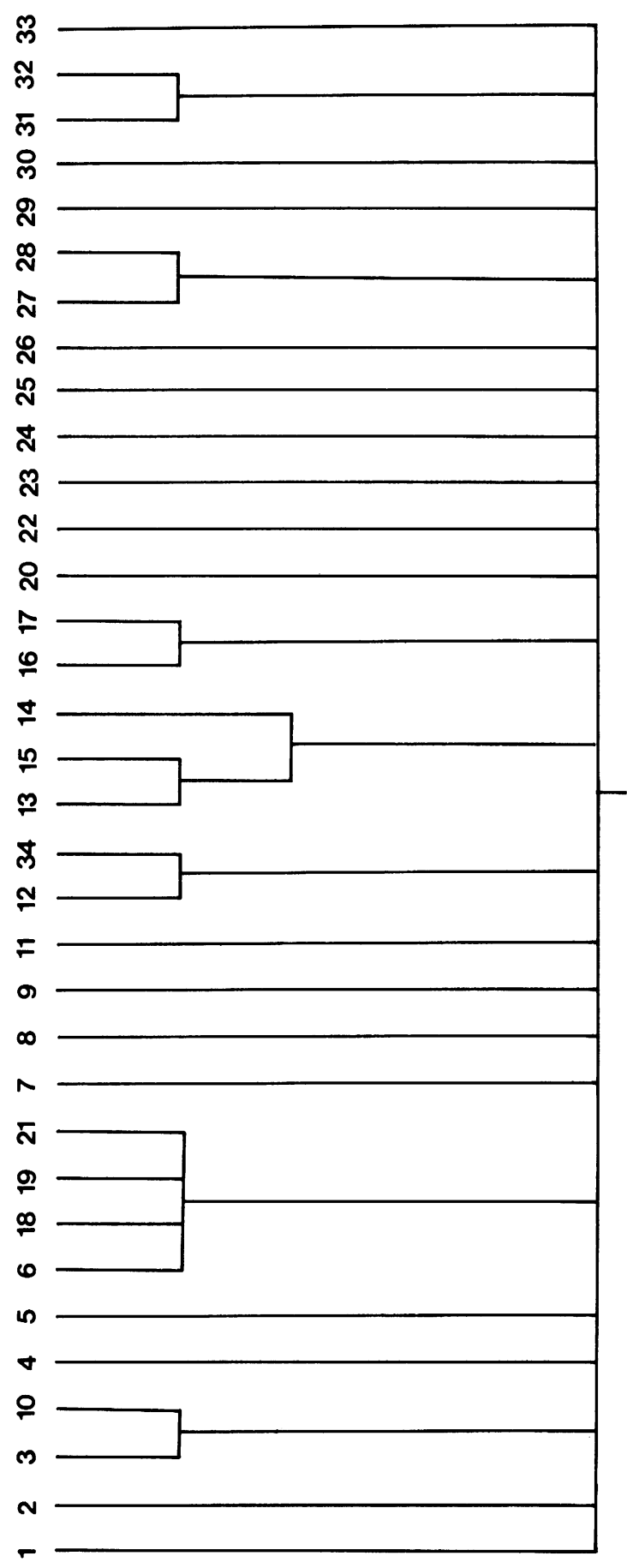

Fig. 6. Consensus tree between undeformed and deformed skulls' phenograms. 
pairs of variables that remain correlated only in deformed (8-7 and 9-24), and 3- pairs that have one variable in common (variable 26 or 4 ).

\section{DISCUSSION}

According to Imbelloni (1925), skull deformations are the result of bio-cultural processes, intentional and unintentional, that lead to the same final result: changes in the shape of the skull. These changes in skull shape can be detected by a combination of craniogeometric variables.

The analysis of variables with the high value of contribution to each principal component, in undeformed and deformed skulls, permits the evaluation of the influence of the deformation.

In undeformed skulls (Table 3), the discriminatory variables are represented by six variables. Two linear variables (19 and 34) that bring their major contribution to PC I and express the skull size differences, and other four angular variables $(21 ; 23 ; 27$ and 31), corresponding to PC II and PC III, express the general conditions of equilibrium between the neurocranial and craniofacial regions.

In deformed skulls (Table 4), the discriminatory variables are seven. Five of them $(11 ; 14 ; 16 ; 17$ and 33$)$ are linear and describe the cranial vault. They mainly contribute to PC II and are associated with shape differences. The remaining variables (29 and 32), which are angular, correspond to PC III. They are related with the position of the

Table 3. Principal components analysis (PCA) in undeformed skulls. Variables with major contribution of the first three components

\begin{tabular}{|c|c|c|c|c|}
\hline $\begin{array}{l}\text { Principal } \\
\text { Components }\end{array}$ & Variables of major contribution & Contribution & $\begin{array}{l}\text { Variation } \\
\%\end{array}$ & $\begin{array}{c}\text { Accumulated } \\
\%\end{array}$ \\
\hline \multirow{5}{*}{ I } & 12. Total length of the horizontal diagonal & 0.840 & \multirow{5}{*}{21.37} & \multirow{5}{*}{21.37} \\
\hline & 10. Total length of the vertical diagonal & 0.832 & & \\
\hline & 34. Glabella-metalambda semidiameter & 0.744 & & \\
\hline & 4. Centro-basifacial radius length & 0.729 & & \\
\hline & 19. Lambda-opisthion chord & 0.718 & & \\
\hline \multirow{5}{*}{ II } & 6. Centro-lambda angle & 0.839 & \multirow{5}{*}{16.20} & \multirow{5}{*}{37.57} \\
\hline & 28. Occipito-basifacial angle & -0.828 & & \\
\hline & 21. Falkenburger II & 0.684 & & \\
\hline & 27. Occipital orientation angle (Reicher II) & -0.587 & & \\
\hline & 23. Facial angle of the lambda & 0.519 & & \\
\hline \multirow{5}{*}{ III } & 5. Centro-bregma angle & -0.758 & \multirow{5}{*}{13.77} & \multirow{5}{*}{51.34} \\
\hline & 31. Imbelloni IV & 0.619 & & \\
\hline & 3. Normal radius length & 0.617 & & \\
\hline & $\begin{array}{l}\text { 26. Relative position between occipital } \\
\text { and parietals }\end{array}$ & 0.594 & & \\
\hline & 4. Centro-basifacial radius length & -0.578 & & \\
\hline
\end{tabular}


Table 4. Principal components analysis (PCA) in deformed skulls. Variables with major contribution of the first three components

\begin{tabular}{|c|c|c|c|c|}
\hline $\begin{array}{c}\text { Principal } \\
\text { Components }\end{array}$ & Variables of major contribution & Contribution & $\begin{array}{c}\text { Variation } \\
\%\end{array}$ & $\begin{array}{c}\text { Accumulated } \\
\%\end{array}$ \\
\hline I & $\begin{array}{l}\text { 4. Centro-basifacial radius length } \\
\text { 33. Radius of the vault length } \\
\text { 5. Centro-bregma angle } \\
\text { 12. Total length of the horizontal diagonal } \\
\text { 26. Relative position between occipital } \\
\text { and parietals }\end{array}$ & $\begin{array}{r}-0.939 \\
-0.897 \\
-0.887 \\
-0.868 \\
0.847\end{array}$ & 30.38 & 30.38 \\
\hline II & $\begin{array}{l}\text { 11. Length of the upper segment of } \\
\text { the vertical diagonal } \\
\text { 17. Bregma-lambda chord } \\
\text { 16. Bregma-lambda curve } \\
\text { 6. Centro-lambda angle } \\
\text { 14. Glabella-bregma curve }\end{array}$ & $\begin{array}{r}-0.846 \\
-0.787 \\
-0.678 \\
0.639 \\
-0.589\end{array}$ & 14.27 & 44.65 \\
\hline III & $\begin{array}{l}\text { 10. Diagonal vertical total length } \\
\text { 32. Basifacial foramen angle } \\
\text { 29. Angle of the foramen plane with } \\
\text { Frankfurt plane } \\
\text { 28. Occipito-basifacial angle } \\
\text { 3. Normal radius length }\end{array}$ & $\begin{array}{r}-0.858 \\
0.720 \\
-0.609 \\
\\
0.550 \\
-0.490\end{array}$ & 12.19 & 56.84 \\
\hline
\end{tabular}

foramen magnum plane in relation to the skull orientation and with the facial pyramid $(\nu-\beta \alpha \sigma-\pi \rho)$. They involve dynamic responses of posture in the presence of different deforming methods.

The number of variables shared by deformed and undeformed skulls is eight, four linear and four angular. The linear variables correspond to the neurocranium polygon and both radii of the craniofacial circumferences (the normal radius and the one related to the facial pyramid base). The four angles are centro-bregma (Herrera Fritot X), the relative position between occipital and parietals (Klaatsch), centro-lambda (Herrera Fritot XI) and occipito-basifacial (Herrera Fritot I). All of them are related with the relative position of the respective linear variables. These results support the hypothesis of the morphological priority of the permanent recomposition of the total skull equilibrium in the human species. Mizoguchi (1991) arrived at the same conclusions as to the regulation of the size and shape of the different portions of the skull. He noted that these regulations occurred as a response to external mechanical factors. The remaining variables do not make any contribution to the explanation of the intrasample variation.

Those variables that remain clustered in both phenograms (Figs. 4 and 5) are as follows: a) normal radius length (3)-total length of the vertical diagonal (10). They express the relationship between the height of the neurocranium polygon and a variable 
of the skull general position. b) total length of the horizontal diagonal (12)-glabella metalambda semidiameter (34). They show that the relationship between the polygon and the vault radius variables is maintained. c) bregma lambda curve (16)-bregma lambda chord (17). This couple of variables depict that the frontal curvature is not altered by deformation. d) occipital orientation angle (27)-occipito basifacial angle (28). The relationship between the two variables of occipital position is maintained independently of the action of deformation loading. e) angle between the foramen's plane and the vertical diagonal (31)-foramen basifacial angle (32). They express the association between two angular values that refer to the foramen magnum position. $\mathrm{f}$ ) length of the anterior segment of the horizontal diagonal (13)-glabela bregma curve (14)-glabela bregma chord (15). The relations among these variables mean that the frontal sector is not altered by deformation. g) centro-lambda angle (6)-lambda opisthion curve (18)-lambda opisthion chord (19)-parallelism between nasion basion and bregma lambda chords (21). The association of the linear and angular variables on the occipital curve with the variables which define the basifacial position, is maintained independently of artificial deformation.

The remaining 17 variables change their relationships. They are all the linear measurements on the neurocranial polygon, which include diagonals, chords and curves; two variables of the skull general position; one variable of craniofacial equilibrium, and one of the vault radius relation. These results support the hypothesis that there is a priority in the biomechanical response to repair the relationships of equilibrium in the cranial vault independently of the facial region. Only the facial pyramid base interferes with the associations, showing that it is a variable of relation between the neurocranium and the splanchnocranium. The relationships with the major mobility are those situated in the sectors that include the lambda, basion and opisthion craniometric points. Anton (1989) has analyzed Peruvian deformed skulls and found variations in the skull base for each type similar to those described in the present study.

There are pairs of variables that remain clustered only in undeformed skulls: a) facial angle of the bregma (22)-angle between opisthion $Z$ and prosthion lambda lines (25) and b) angle between the foramen's and Frankfurt planes (29)-occipital angle of foramen's plane (30). Both refer to the occipital position specially associated with the foramen magnum plane orientation.

The pairs of variables that remain clustered only in deformed skulls are: a) angle of the nasion basion diameter with the Frankfurt plane (8)-angle of the basion in the facial pyramid (7) and b) central angle of the diagonals (9)-interoccipital angle (24). The associations refer to angular values of general position of the facial pyramid and the occipital sectors.

There are also, pairs of variables that have one element in common. This is the case of variables 26 (relative position between occipital and parietals) and 4 (centrobasifacial radius length). Variable 26 is associated with 23 (facial angle of the lambda) in 
undeformed and with variable 1 (angle of the vertical diagonal with the bregmatic vertical) in deformed. This supports the idea that the artificial deformation modifies the position of lambda and probably that of basion causing the differential variation of the two angles that have lambda as their vertex. Thus, changes are not produced in the same direction for the position of the nasion-lambda and basion-lambda segments to the bregma-lambda and opisthion-lambda chords. Variable 4 is associated with 5 (centrobregmatic angle) in undeformed and with variable 33 (radius of the vault length) in deformed. This expresses that the equilibrium between the occipital and parietal bones is modified towards an equilibrium between the frontal and parietal bones in the presence of artificial deformation.

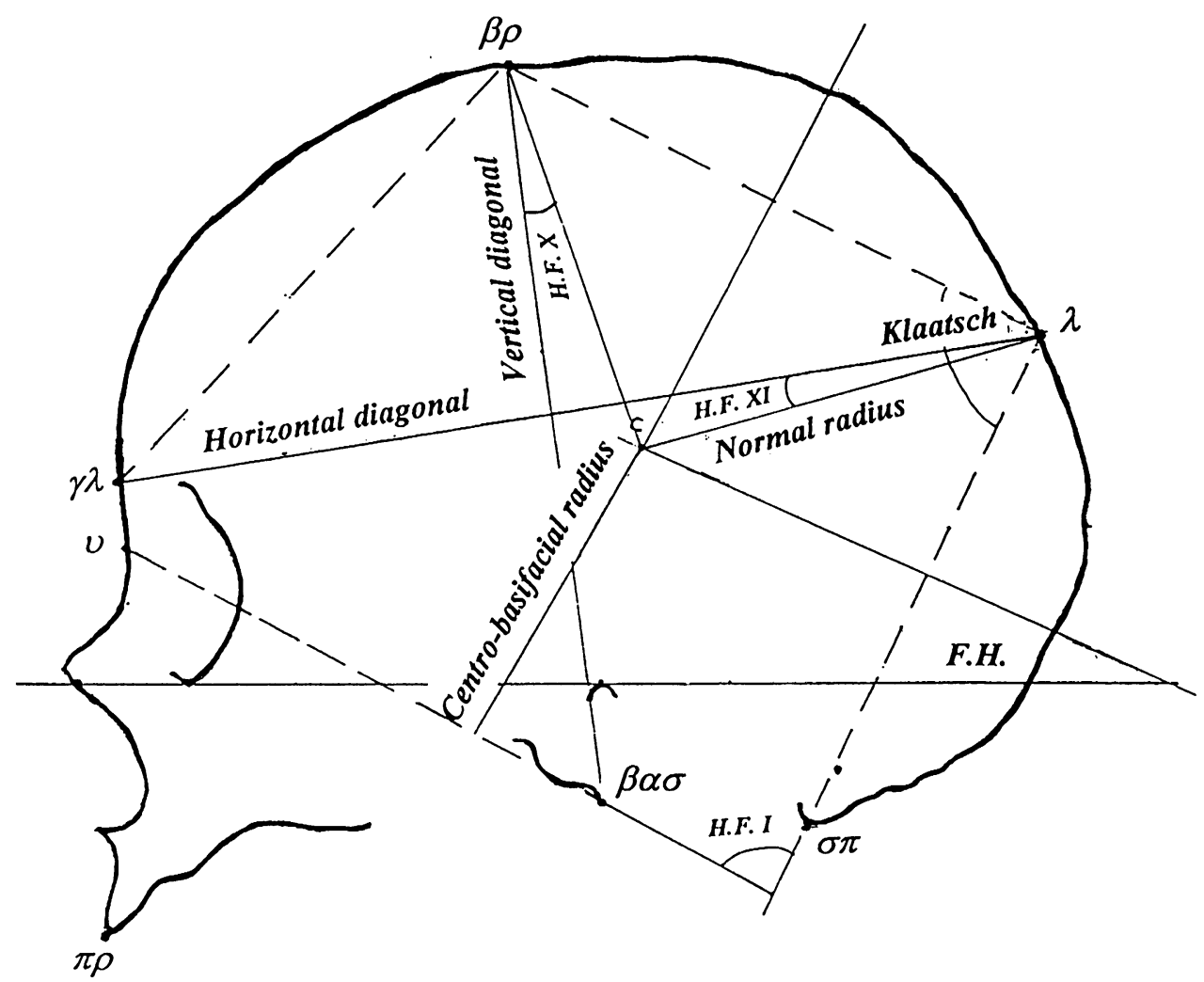

Fig. 7. Sagittal norm with the set of discriminatory variables for undeformed and deformed skulls. $\pi \rho=$ prosthion; $\nu=$ nasion; $\gamma \lambda=$ glabella; $\beta \rho=$ bregma; $\lambda=$ lambda, $\beta \alpha \sigma=$ basion; $\sigma \pi=$ opisthion; F.H.=Frankfurt horizontal; H.F.I=Herrera Fritot I; H.F.X=Herrera Fritot X; H.F.XI=Herrera Fritot XI.

\section{CONCLUSIONS}

The present study shows that: 1 - The artificial deformation modify the discriminatory expression of craniogeometric variables. 2- The analysis of the variation in Patagonian skulls demonstrates that the diagnostic variables are the set of variables common to 
undeformed and deformed skulls with the major discriminatory value (Fig. 7): centrobasifacial radius length (4), total length of the horizontal diagonal (12), centrobregma angle (5), relative position between occipital and parietals (26), centro-lambda angle (6), total length of the vertical diagonal (10), occipito-basifacial angle (28) and normal radius length (3). 3- The substantial relationships among variables are those that remain in the presence or absence of artificial deformation. 4- The artificial deformation produces new associations among variables that in general tend to repair the equilibrium conditions. 5- In deformed skulls the occipital is the region mostly affected while the frontal and the facial pyramid are the most stable ones.

\section{ACKNOWLEDGEMENTS}

The authors are grateful to Beatriz Sutton and Carol Sutton for their final revision of the paper.

\section{REFERENCES}

Anton, S.C. (1989) Intentional cranial vault deformation and induced changes of the cranial base and face. Am. J. Phys. Anthropol. 79(2), 253-267.

Bórmida, M. (1953/54) Los antiguos patagones. Estudio de craneología. RUNA VI 1-2, 5-96.

Colantonio, S.E., and Marcellino, A.J. (1983) Relaciones morfológicas de los aborígenes prehispánicos del territorio argentino. IV: Patagones de Río Negro y Chubut. PUBLICACIONES del Inst. de Antrop. Univ. Nac. de Córdoba. XLI, 31-49.

Colantonio, S.E., Marcellino, A.J., and González Toledo, E.C. (1984) Normalización de una técnica derivada de la orientación vestibular. III: deformación tabular erecta. PUBLICACIONES del Inst. de Antrop. Univ. Nac. de Córdoba. XLIII, 7-32.

Dembo, A., and Imbelloni, J. (1938) Deformaciones intencionales del cuerpo humano de carácter étnico. Humanior. Seccion A. Tomo III. Buenos Aires.

Falkenburger, F. (1912) Zur Craniotrigonometrie. Korrespondenzblatt der Deutschen Gesellschaft für Anthropologie 43, 126-128.

Falkenburger, F. (1913) Diagraphische Untersuchungen an normalen und deformierten Rassenschadeln. Archiv für Anthropologie N.F. 12, 81-95.

Falkenburger, F. (1938) Recherches anthropologiques sur la déformation artificielle du cráne. J. de la Soc. des Am. 3, 1-69.

Falkenburger, F. (1941) Sur quélques nouvelles corrélations craniennes. Rev. del Inst. Antrop. de Tucumán. 4, 67-79.

Ferembach, D., Schwidetzky, Y., and Stloukal, M. (1977/78) Raccomandazioni per la determinazione dell'età e del sesso sullo scheletro. Riv. di Antrop. LX, 5-51.

Herrera Fritot, R. (1964) Craneotrigonometría, Comisión Nacional de la Academia de Ciencias, Cuba. Imbelloni, J. (1921) Introducción a nuevos estudios de craneotrigonometría. An. Mus. Nac. Hist. Nat. XXXI.

Imbelloni, J. (1925) Deformaciones intencionales del cráneo en Sud América. Rev. del Mus. de La Plata XXVIII, 329-407.

Klaatsch, H. (1909) Kraniomorphologie und Kraniotrigonometrie. Archiv. für Anthropologie N.F. 8 Braunschweig.

Lissauer, A. (1885) Untersuchungen über die sagittales Krummung des Schadels bei den Anthropoiden 
und den verscheidenen Menschenrassen. Archiv für Anthropologie 15 (Suppl.), 9-119.

Marelli, C. (1914) Contribución a la craneología de las primitivas poblaciones de la Patagonia (Observaciones morfobiométricas). An Mus. Nac. de Hist. Nat. XXVI, 31-91.

Marelli, C. (1919) Nuevas investigaciones biométricas sobre las primitivas poblaciones de la Patagonia. An. Mus. Nac. de Hist. Nat. XXX, 197-236.

Méndez, M.G., and Salceda, S.A. (1995) Metrical and non-metrical variants in Argentine prehistoric populations. Riv. di Anthropol. (in press).

Mizoguchi, Y. (1991) Covariations in craniofacial measurements caused by artificial deformations of the cranial vault. Bull. Natn. Sci. Mus., Tokyo, Ser. D. 17, 31-50.

Moss, M.L., and Young, R. W. (1960) A functional approach to craniology. Am. J. Phys. Anthropol. 18, 281-292.

Rohlf, F.J. (1982) Consensus indices for comparing classifications. Math. Biosci. 59, 131-144.

Rohlf, F.J. (1992) NTSYS-pc. Numerical taxonomy and multivariate analysis system. Ver. 1.7. Exeter software, Setauket. New York.

Schuh, R.J., and Polhemus, J.T. (1980) Analysis of taxonomic congruence among morphological, ecological and biogeographical data sets for the Leptopodomorpha (Hemiptera). Syst. Zool. 29, 1-26.

Sollas, W.J. (1933) The sagittal section of the human skull. J. of the Roy. Anthropol. Inst. 63, 389-431.

Sokal, R.R., and Rohlf, F.J. (1962) The comparison of dendrograms by objective methods. Taxon. 11, 33-40.

Sokal, R.R., and Rohlf, F.J. (1981) Taxonomic congruence in the Leptopodomorpha reexamined. Syst. Zool. 30, 309-325.

Stamrud, L. (1959) External and internal cranial base. Acta Odontol. Scand. 17, 239-266.

Tedeschi, E.E. (1916) Nuovi problemi di geometrica cranica. Riv. di Antropol. XX, 85-93. 